\title{
63. Enigmatic Hints at the Hidden Meaning of Two Central Homeric Passages. The Derveni-Author as Homeric Philologist in PDerv. col. XXVI
}

\author{
Anton BierL \\ Universität Basel
}

The poem of Orpheus defamiliarizes, de-establishes fixed meanings, loosens the link between signifier and the signified and occupies a zonal territory between them. ${ }^{1}$ Therefore, it seems to be riddling or enigmatic for average people. Yet according to the Derveni author, Orpheus did not intend to use this technique for contentious purposes, that is, to show off in a rhetorical $\dot{a} \gamma \omega \dot{\omega} v$. On the contrary, he wanted to say great things in riddles, that is, he

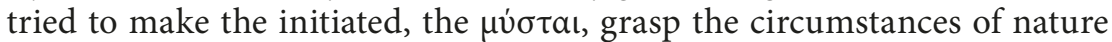
and кó $\mu_{0}$ (cf. col. VII). It is this hidden sense that the Derveni author wants to bring out by using hermeneutical methods. For him, everything boils down to a problem of language: people tend to err through incorrect nominations (óvó $\mu \alpha \tau \alpha$ ), since the language of $\varphi v \dot{\sigma} \iota \varsigma$ or the gods is basically

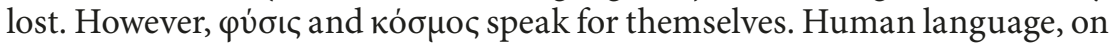
the contrary, is not $\varphi v ́ \sigma \varepsilon$, but vó $\mu \omega$, by convention or $\theta \varepsilon \dot{\varepsilon \varepsilon t . ~ Y e t ~ s o m e ~ g r e a t ~}$ poets and guru-prophets might still have access to pure $\varphi v$ vis and physical language. Through games of language, as well as textual and hermeneutical strategies, the true, mystic sense can be reinstalled.

Orpheus' theogony is pure poetry, thus composed of óvó $\mu$ ata. According to the Derveni author, Orpheus' poem pays credit to the taste of the masses, since they demand the existence of mythological figures. Popular myth emphasizes the birth, death, and succession of generations who are in power. For the masses, myth operates on the basis of purely anthropomor-

1 It is my pleasure to contribute to this volume in honor of Alberto Bernabé, whom I admire as great colleague, philologist, leader of 'Orphic' circles in Madrid, and Dionysiac friend. I met him for the first time at the Conference on the Derveni Papyrus at the Center for Hellenic Studies (2008). Therefore, I want to dedicate to him these thoughts on a text to whose understanding he offered so much. The Greek text is cited according to Kouremenos - Parássoglou - Tsantsanoglou (2006), the translation of col. XXVI as well (ibid. 139). The basic hypothesis of my paper just appeared in Bierl (2011b) in the Proceedings of the CHS conference edited by Papadopoulou and Muellner (2011). 


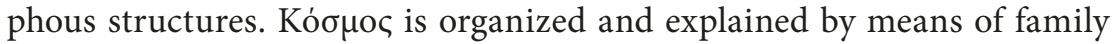
analogies. Sexual intercourse, often familiar as with incest or exogamous, can explain the birth of new filiations. Castration, on the other hand, is the means to prevent such power politics through sex. Thus, he polemicizes

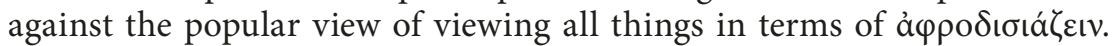

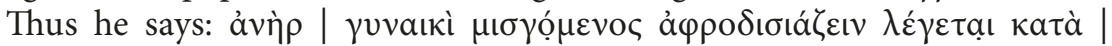

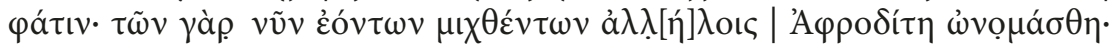
("A man mingling is said by common diction to 'aphrodize'. For this reason, since the things are mixed with one another, it was called Aphrodite", col. XXI 7-10). Moreover, cosmological development is narrated in terms of Love and Strife. Thus in myth, progress and succession occur by means of violent overthrows, murder, and exile. Philosophers and intellectuals soon regarded these traditional stories as scandals. One way to explain them away was the invention of allegory. However, our Derveni author is not only a simple allegorist, but aside from his target-discourse of contemporary natural science as púrıs, at the same time he is strongly embedded in the Orphic system himself. Thus, he resorts to a very specific set of hermeneutical tools, namely, allegoresis, paretymology and philological interpretation on the micro-level, as well as fragmentation via decontextualization paired with his own riddling strategies. By these means of distorting, twisting and changing sense, he introduces a radical Umwertung of values and meanings. What our author exactly intends with such enigmatic utterances often remains open. Therefore, the Derveni Papyrus is not a clear-cut and lucid commentary in terms of Presocratic natural science. Rather, by means of

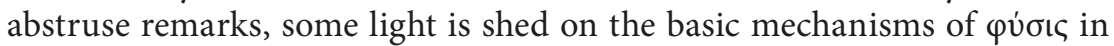
terms of the author's Orphic ideas.

Thus, the Derveni author conveys the central Orphic idea of cyclicity by systematically downplaying the violent succession of mighty divine rulers.

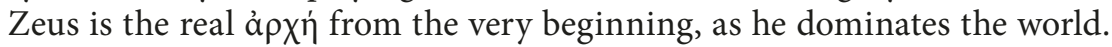
By means of an in medias res order and ring composition, the importance of Zeus, the guarantor of this kó $\sigma \mu \mathrm{o}$, is mirrored on the level of composition and poetic structure. ${ }^{2}$ Therefore, the Olympian ruler is paradoxically identical to all of the former personifications in the process of evolution. Moreover, the author is keen to eradicate the notorious stories of sexual affairs. The last column (XXVI) is a good example of the latter tendency, since he deconstructs Orpheus' version of the story of the incest between Zeus and Rhea/ Demeter from which Persephone, Dionysus' mother, is born. ${ }^{3}$

If Zeus encompasses all gods, we assume that he has also had his mother inside of him. Therefore, sexual generation is impossible, and mother is just another metaphor for Mind. The author then bases his argument on the mi-

2 On the "flashback device", see Bernabé (2007: 113-114).

3 See Bernabé (2007: 121-122). 
cro-linguistic level by playing with the ambiguities of sound. In doing so, he comes very close to the practice of early Alexandrinian philology and its $h y$ pomnema exegesis. By overlapping the genitive of the feminine adjective of żú with the feminine possessive pronoun of żóc, the inventive, intellectual commentator claims that Zeus' new creation does not come from 'his own'

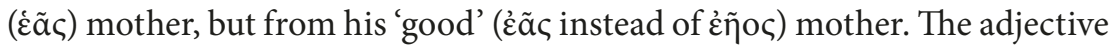
Év́ is not, of course, identical to the possessive pronoun żóc. However, such an erroneous confusion was quite frequent in grammarians. ${ }^{4}$ The Mother is good and, of course, Zeus does not mingle with his mother in love, but with Mind - it is identical with the good Mind, the mother of all.

The entire linguistic argument seems to be born in Homeric philology, and therefore he will resort to canonical Homeric examples as well. Thus he cites the formula "Hermes, the giver of goods", $\delta \tilde{\omega} \tau o \rho$ żá $\omega v$, in Od. $8.335^{5}$

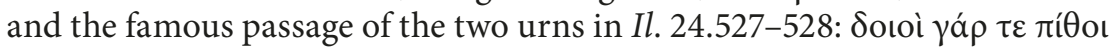

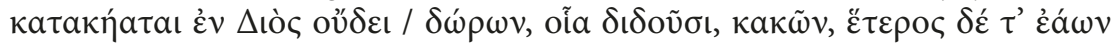
("for two urns are placed down on Zeus' floor - of gifts such as they give: of evils, and the other one of goods ( $\left.\varepsilon^{\alpha}(\omega v) "\right) .{ }^{6}$ Besides the linguistic sophistry, the reference to Hermes and to these specific passages might not be accidental. As $\psi v \chi \chi о \pi о \mu \pi$ ó, Hermes is linked to Hades and the passage into the underworld where all goods are waiting if you behave as is ritually and intellectually proper. What is harmful has to be changed into good.

Furthermore, the first quotation is derived from Demodokos' song of Ares and Aphrodite (Od. 8.266-366). The burlesque story is not proof of a new and younger spirit of the time, and thus a later addition or digression, but rather is rooted in very old traditions and is perfectly integrated into the text by reflecting the entire Odyssey in a sort of a mise en abyme, as I argue elsewhere. ${ }^{7}$ The grotesque and comic divine narration can already be found in Hittite texts that, as is well known, had a strong influence on the Homeric tradition. ${ }^{8}$ The Homeric scene is located at the Phaeacian court, a sort of otherworld associated with Hades. Negative traits merge with features like love, luxury, feast, poetry and chorality. ${ }^{9}$

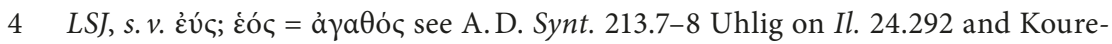
menos - Parássoglou - Tsantsanoglou (2006: 271) ad loc. and Jourdan (2003: 104105). The play on semantic ambiguity is easier to grasp if we print in col. XXVI 2 $\dot{\varepsilon} \tilde{a} \varsigma$, as Jourdan (2003: 26) and Betegh (2004: 54-55), instead of $\dot{\varepsilon} \tilde{a} \varsigma$, as Kouremenos - Parássoglou - Tsantsanoglou (2006: 113) and Janko (2002: 52).

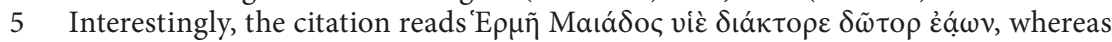

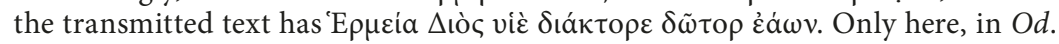
8.325 , and in the passage of $I l .24 .528$ do we have the variant with spiritus asper

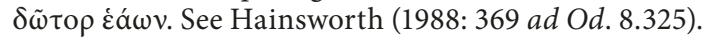

6 See also Brügger (2009: 189 ad loc.).

7 Cf. Bierl (2010).

8 Cf. Burkert (1960: 133 with n. 5; 1982).

9 Cf. Bierl (2010). 
The story of the clandestine love affair notionally returns to an oral pre-stage of the monumental epic performed in the regulated, recitative form of Homer. ${ }^{10}$ Embedded as a further recessed pre-stage, in the first and third song of Demodokos, this song accompanied by a mute chorus of dancers represents, according to Greg Nagy, a pure lyric hymnos without the pars epica after the transitional formula, as represented in the later Homeric Hymns. ${ }^{11}$ In addition, the contents deal with Aphrodite and love, just as in the Derveni text at this point. To some extent, the song of Ares and Aphrodite seems to integrate Orphic and pre-Homeric traditions that refer to cosmic love and circularity. Moreover, Ares and Aphrodite are not only deactivated by Hephaistos' chains, but also their love finds its concrete expression in absolute union; the concatenated bodies of the lovers could be imagined in form of a ball. By the intervention of Poseidon, the bond is dissolved again and both gods, the personification of love and war, can walk away in freedom. Thus, it is conceivable that there have been attempts in ancient scholarship to link the song with Empedocles. ${ }^{12}$ This Presocratic philosopher who introduces Philotes and Neikos as the principles of cosmic developments has been frequently associated with Orphic ideas. ${ }^{13}$ Strife dissolves the total union of Love, symbolized in the ball or $\sigma \varphi \alpha$ ĩ $\rho \alpha,{ }^{14}$ until we return again to the maximum state of Philotes after one turn of the great cycle. In the same way, the loosening of the fetters dissolves the total union of a cosmic bond and helps Aphrodite once more to begin a new affair on the basis of deceit and guile that lead to quarrel, strife and war.

Thus, the citation from the song of Ares and Aphrodite (Od. 8.266-366) could be read as an allusion to a higher form of Orphic Love, and the following choral dance $(O d .8 .370-381)$ with a ball ( $\sigma \varphi \alpha \tilde{\rho} \rho \alpha)(O d .8 .372)$ might reflect this background as well. In addition, in the Homeric hymnic narration, Hermes plays the role of the keen and lustful lover (Od. 8.323-342). When the phallic trickster god who disrupts and transcends all boundaries, but

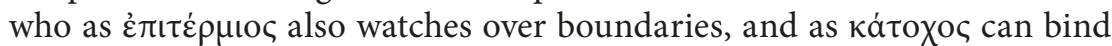
evil-doers by keeping them beneath the earth via magical spells, is asked whether he would not love to lie, even in chains, with golden Aphrodite

10 Cf. Bierl (2011a). On all three songs of Demodokos as pre-stages of Homer, cf. inter al. Gentili in Gentili - Giannini (1977: 7-37) and Gentili (1984: 18-21; new edition 31-34). On the singers in Homeric epic in general, cf. references in de Jong (2001: 191, n. 2). On the idealization of the portrayal, see e.g. Segal (1994: 116).

11 On this subject, see Nagy (2008-2009: 313-342, 2\$\$274-331; 2009-2010: 1\$\$210241). On Demodokos, see now Krummen (2008: 18-23) and Nagy (2008-2009: 313-353, 2\$\$274-350; 2009-2010: 1\$\$188-241).

12 The song was especially linked to the Empedoclean concept of philotes (Emp. fr. 35 DK); Burkert (1960: 133, n. 6) refers to Heracl. All. 69 and Sch. ad Od. 8.267; Eust. 1298.34 ad Od. 8.267. See also Nagy (2009-2010: 1\$208).

13 Inter al. Riedweg (1995).

14 Cf. Emp., esp. frs. 27-30 DK. 
in bed (Od. 8.335-337), his answer is more than affirmative. Even if three times as many or innumerable chains were to hold him, and all of gods and goddesses were to watch them who now stay away out of shame, he would

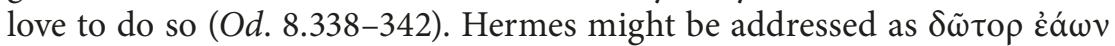
because, in a way, he functions as a primordial personification of male love.

The second Homeric citation is found in the famous scene where Priam visits his archenemy Achilles in his tent. The whole design of the story has been associated with a katabasis. In Alberto Bernabés circle, his pupil Miguel Herrero de Jáuregui has recently explored all the resonances with Orphic gold-leaves and death experience in a systematic way. ${ }^{15}$ Of course, it is Hermes again who as $\psi v \chi 0 \pi о \mu \pi$ ó $\zeta$ has to lead him into Achilles' tent, a journey into a sort of otherworld and death. In the famous supplication scene, both are at first united in lament about the death of their loved ones (Il. 24.468-512). At last, Achilles takes pity on Priam (Il. 24.513-516). Thus, in his following consolation speech, Achilles uses the famous example of the two jars (Il. 24.525-533) and, in analogy, applies it to the destiny of Peleus (Il. 24.534-542) and Priam (Il. 24.543-548). The image of the $\pi i \theta$ or filled with different qualities on Zeus' floor shows that Zeus epitomizes and encompasses everything, including all binary opposites, even good and evil. This concept again suits the situation of the chthonic Hades and Orphic doctrine, since moral behavior is decisive for whether the $\delta \varepsilon v$ á of Hades can turn out well, or whether death can be reverted to life.

Reading Orpheus as well as Homer, therefore, is like a profound associative technique similar to the understanding of an oracle. The Derveni author tries to decipher $\sigma \eta \mu \varepsilon \tilde{c}_{\alpha}$, textual signs. Yet he does not make everything clear but only gives hints, riddling himself. In this respect, he is similar to

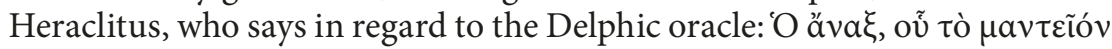

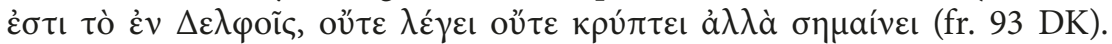
Cryptic and enigmatic language in the manner of an exegesis of dreams and oracles is exactly the strategy of our anonymous, extraordinary practitioner to involve the recipient and produce deeper insight. Even the two Homeric citations that on the surface just seem to have the function of providing evidence for a specific linguistic use refer to a deeper meaning: they are linked to the entire ideological system, namely, Orphic ideas of katabasis, the alternation of Love and Strife, life and death, and the paradoxical interaction between them in a physis as expression of perfect, cosmic harmony.

15 Herrero de Jáuregui (2011). On occasional "catabatic readings", see the extensive reference to literature ibid. n. 1; and the new commentary by Brügger (2009: $121 \mathrm{ad}$ Il. 24.328). 


\section{Bibliography}

Bernabé, A. 2007: «The Derveni Theogony: Many Questions and Some Answers», HSCPh 103, 99-133.

Betegh, G. 2004: The Derveni Papyrus. Cosmology, Theology and Interpretation, Cambridge.

Bierl, A. 2011a: «Demodokos' Song of Ares and Aphrodite in Homer' Odyssey (8.266366) - an Epyllion? Agonistic Performativity and Cultural Metapoetics», Brill's Companion to Greek and Latin 'Epyllion' and Its Reception, Baumbach, M. - Bär, S. (eds.), Leiden.

- 2011b: «'Riddles over Riddles': 'Mysterious' and 'Symbolic' (Inter)textual Strategies. The Problem of Language in the Derveni Papyrus», Papadopoulou, I. - Muellner, L. (eds.).

Brügger, C. 2009: Homers Ilias. Gesamtkommentar VIII: Vierundzwanzigster Gesang (eds. Bierl, A. - Latacz, J.), Berlin - New York.

Burkert, W. 1960: «Das Lied von Ares und Aphrodite. Zum Verhältnis von Odyssee und Ilias», RhM 103, 130-144.

- 1982: «Götterspiel und Götterburleske in altorientalischen und griechischen Mythen", Eranos-Jb 51, 335-367.

de Jong, I. 2001: A Narratological Commentary on the Odyssey, Cambridge.

Gentili, B. 1984: Poesia e pubblico nella Grecia antica da Omero al V secolo, Roma - Bari (new edition Milano, 2006).

Gentili, B. - Giannini, P. 1977: «Preistoria e formazione dell'esametro», QUCC 26, 7-51.

Hainsworth, J. B. 1988: «Book VIII». A Commentary on Homer's Odyssey. Vol. 1: Introduction and Books i-viii, Heubeck, A. - West, S. - Hainsworth, J.B., Oxford, 341-385.

Herrero de Jáuregui, M. 2011: «Priam’s Catabasis: Traces of the Epic Journey to Hades in Iliad 24», TAPhA 141, 37-68.

Janko, R. 2002: «The Derveni Papyrus: An Interim Text», ZPE 141, 1-62.

Jourdan, F. 2003: Le Papyrus de Derveni. Texte présenté, traduit et annoté, Paris.

Kouremenos, T. - Parássoglou, G. M. - Tsantsanoglou, K. 2006: The Derveni Papyrus. Edited with Introduction and Commentary, Firenze.

Krummen, E. 2008: «'Jenen sang seine Lieder der ruhmvolle Sänger ...' Moderne Erzähltheorie und die Funktion der Sängerszenen in der Odyssee», A\& A 54, 11-41.

Nagy, G. 2008-2009: Homer the Classic, Cambridge MA - Washington DC. The 2008 online version is available at http://chs.harvard.edu. The printed version appeared 2011.

- 2009-2010: Homer the Preclassic, Berkeley - Los Angeles CA. The 2009 online version is available at http://chs.harvard.edu. The printed version has appeared 2011.

Papadopoulou, I. - Muellner, L. (eds.) 2011: Proceedings of the Derveni Papyrus Conference. Center for Hellenic Studies July 7-9, 2008, Washington DC. An electronic prepublication in Classic@ issue 5 is posted on the CHS website http://chs.harvard.edu/wa/pageR?tn=ArticleWrapper\&bdc=12\&mn=3871

Riedweg, C. 1995: «Orphisches bei Empedokles», A\&A 41, 34-59.

Segal, C. 1994: Singers, Heroes, and Gods in the Odyssey, Ithaca - London. 